\title{
Legal and Psychiatric Concepts and the Use of Psychiatric Evidence in Criminal Trials
}

Courts vary in their willingness to accept criminal defendants' offers of expert psychiatric ${ }^{1}$ testimony. One reason for resistance to the use of psychiatric knowledge by the law is lingering doubt about the scientific validity of psychiatry. However, legal decisionmakers are also concerned that incorporation of psychiatric concepts into the crimmal law will impair the ability of the law to achieve its policy objectives. They fear two developments: one, that psychiatrists will have increasing influence on ultimate legal determinations; and two, that the law will become dependent on concepts that belong to an outside discipline.

This Comment contends that the law slould not attempt to be progressive by incorporating psychiatric concepts or analyses into legal standards. Rather, the law should use broad, familiar, psychiatrically naive standards. Psychiatric explauations of behavior slould then be used to enlighten judges and juries as they apply these standards to the circumstances of specific defendants. This approach minimizes encroachment on the decisionmaking authority of the courts and does not threaten psycliatric dommation of legal concepts. It slould therefore be more acceptable to legal decisionmakers.

Part I of this Comment exammes possible relationships between psychiatric and legal concepts and their potential for disruption of the legal system. It then suggests that legal decisionmakers react to disruption (or threatened disruption) mucl as scientists do when they face cliallenges to existing theoretical paradigms. Both try to limit the disruption so as to continue solving problems within the paradigm unless a better paradigm is available. Part II examines this paradigm-protection response, as exemplified by judicial and public reaction to the diminislied capacity defense. It contrasts this reaction with other situations in which the threat of disruption lias been less apparent. Finally, Part III suggests how the law can use psychiatric infornnation sensitively without losing control over its own policy objectives.

1. The term "psychiatry" is used thronghout this Comment because, of the sciences concerned with the understanding of human behavior and mental hife, psychiatry has been most heavily employed in court. However, the same underlying issues and problems can, as this Comment shows, arise from sociological, psychological, or other scientific advances that provide insights into the determinants of human behavior. 
I

\section{LaW and Psychiatry: Different Goals and OVERLAPPING CONCERNS}

The criminal law looks beyond the deed to the mental state of the wrongdoer in determining its response to the wrongful act. ${ }^{2}$ Guilt involves more than a determination that the person did the forbidden deed. It is a " 'something more' [that] depends on the functions thought to be served by punishinent, and is instrumental in performing those functions."3

Psychiatry would appear to be of great use to any legal analysis that considers the wrongdoer's mental state. However, the role of psychiatry in the law may well be hinited by policies underlying the legal systenr. ${ }^{4}$ As Professors LaFave and Scott observe, "[t]he purpose of the criminal law is to prevent certain undesirable conduct and thus protect various interests of society." All theories of punishnient, whatever their other differences, share this value of societal protection. ${ }^{6}$

Thus, no matter how much information psychiatry provides about criminal behavior, legal pohicymakers will continue to enact laws with an eye toward protecting society. As psychiatry beconies better able to explain behavior, the law may cone to doubt the justice or utility of some of the punishments it inflicts. However, as long as society requires protection, policies must be set and balances struck. These policies will not necessarily fully reflect psychiatric explanations of behavior or mental life. ${ }^{7}$ The crucial issue is how to structure the relationship

2. Even theorists whose views are otherwise radically different consider mental state critical in determining the law's response. See, e.g., B. WootTon, CRIME AND THE CRIMINal LAW 52-53 (1963) (under the behavioral view, the actor's state of mind in advance of the offense does not figure in the initial adjudication, but should be considered in determining what action society should take to prevent a recurrence); Kadish, The Decline of Innocence, 26 CAMBRIDGE L.J. 273, 273-75, 285-90 (1968) (inquiry into the actor's state of mind is a prerequisite to determining if a crime has been committed at all, for the state of mind helps to define the very behavior that the law seeks to prevent).

3. H. Packer, The Limits of the Criminal Sanction 18 (1968).

4. This Connnent is concerned with the relationship between psychiatry and law as conceptual systems-one scientific and the other designed to achieve social goals. It does not address the implications of psychiatry, if any, for what those goals should be or how principled restrictions on the actions of the law should figure into goal setting in order to assure individual freedom.

5. W. LAFAve \& A. Scott, HaNdBook on CRiminal LAW § 5, at 21 (1972).

6. See id. at 21-24.

7. The difference between the goals of psychiatry and the law may lie at the heart of somc judicial refusals to be guided by psychiatric testimony. See, e.g., State v. Sikora, 44 N.J. 453, 476-79, 210 A.2d 193, 204-07 (1965) (Weintraub, C.J., concurring). In that case, Chief Justice Weintraub cominented on an expert witness' theory that the defendant's unconscious coinmanded that he kill to prevent the disintegration of his personality, observing in part:

Now this is interesting, and I will not quarrel with any of it. But the question is whether it has anything to do with the crime of inurder. I think that it does not.

...

What then shall we do with our fellow automaton whose unconscious directs such 
between legal and psychiatric concepts so that psychiatric information is useful to the law but does not threaten its social goals. ${ }^{8}$

\section{A. Types of Relationships Between Psychiatric and Legal Concepts}

In judging a criminal case, the court takes into account various exculpatory and imculpatory elements. Some will touch upon matters where psychiatry may be helpful; others will not. If the police found the accused holding a bloody knife over the victim's body, psychiatric evidence would probably not be useful in resolving any disputes over the discovery itself. However, psychiatry inay help to determine whether the accused acted out of fear for his life, whether he appreciated the fact that he could kill somebody by stabbing, and how maturely he could reflect upon his actions.

The four relationships between psychiatric concepts and legal concepts discussed below represent points along a continuum of possible relationships. As one moves along the continuuin, psychiatry and the law come increasingly to speak in the same or similar terms. As a shorthand, one might say that their respective discourses become increasingly similar.

At one end of the continuum, to know the psychiatric conclusion is

antisocial deeds? For one thing, we could say it makes no difference . . . where within the mind the evil drive resides.

Or we could inodify the law's concept of mens rea to require an evil-meaning unconscious. The possibilities here are rich. .. . Shall we indict for murder a inotorist who kills another because, although objectively he was negligent at the worst, the psychoanalyst assures us that the conscious man acted autonatically to fulfill an unconscious desire for self-destruction? All of this is fascinating, but much too frothy to support a structure of criminal law.

Id. at 476-78, 210 A.2d at 205-06 (Weintraub, C.J., concurring).

8. Professors Louisell and Diamond point the way toward such an analysis:

The behavioral sciences can assist the law further to evolve the operational meanings of its time-honored words. The definitions of such terms as intent, malice, premeditation, insanity, responsibility, depravity, turpitude, negligence, passion, and many kindred words in our penal codes seem to be largely products of the ethos of the generation, as are "due process" and "equal protection." Good could be accomplished by evolving newer and inore insightful meanings for these words and phrases which would refleet advances in our scientific knowledge of human behavior, when in fact there have been advances. . . The behavioral sciences, espeeially psychiatry, ean contribute to such a process of evolutionary development.

Louisell \& Diamond, Law and Psychiatry: Détente, Entente, or Concomitance, 50 CoRNEll L.Q. 217, 233 (1965) (footnotes omitted).

Insofar as psychiatric advances serve to clarify the distinctions that the law has drawn as a matter of policy, the results will almost certainly include some evolution in the meanings of legal terms. However, if psychiatry begins to push beyond that and threatens to infringe on the ability of the law to carry out its social policies, then the law may react to preserve its control.

Psychiatric advances may not always enhance the value of the information that psychiatry provides to the law. See, e.g., Diamond, From Durham to Brawner, A Futile Journey, 1973 WASH. U.L.Q. 109, 115 (arguing that recent advances in psychiatry have led to such confusion concerning basic premises that useful psychiatric mformation is now less readily conveyed to the courts than it formerly was). 
to know the legal one. The law could, for example, equate "legal insanity" with "clinical insanity" and rely on psychiatry to determine the defendant's status. Or, it could depend on psychiatry to define mens rea elements such as "premeditation" and to ascertain their presence or absence in individual cases. At this extreme, one might suppose that the inquiry should be turned over to psychiatrists if they become able to determine what thoughts the defendant actually entertained. ${ }^{9}$ Such a close relationship is likely to be very rare in practice.

Moving along the continuuin, psychiatric concepts may inform legal concepts. In this relationship, legal and psychiatric terms are not coterminous, but the psychiatric analysis is powerfully suggestive of the proper legal one. For example, the law might be concerned with psychiatric evidence that indicates whether or not an accused was able to formulate certain thoughts upon which legal "sanity" turns. Or, the psychiatrist may inform the court about what thoughts the defendant harbored and when they arose. This testimony could be calculated to correspond to the attributes of, for example, premeditation.

Further along, psychiatry may advise the law about the defendant's mental processes. The law may consider the advice in assessing where the defendant falls relative to some legally important line that is itself stated in essentially nonpsychiatric terms. For example, psychiatry might explain how the accused's cultural background, family history, and peculiar sensibilities caused him to be provoked, to perceive danger, or otherwise to respond as he did in a given situation. The factfinder could then use this information to determine whether the accused's response was reasonable under the circumstances, whether society can accept the risk of a repetition of the act, and like matters.

Finally, psychiatric information may have no utility whatsoever. For example, in a truly strict liability crime, the mental state of the offender or his motivations would be irrelevant.

\section{B. The Potential for Disruption and the Relationship of Legal and Psychiatric Concepts}

To the extent that the law is concerned with the inental state and the motivations of the wrongdoer, it makes sense to use psychiatry to advance the inquiry. The problem is how best to use psychiatry as a tool without disrupting (or appearing to disrupt) the law's ability to achieve its goals.

The solution to this problem begins with the simple observation that the law is a social enterprise and psychiatry a scientific one. The law

9. This position is not entirely farfetched. The Supreme Court of Pennsylvania has faced a very similar claim. See infra note 93 . 
exists to achieve a number of social policy goals, prominent among them the protection of the community from those who violate social standards. Thus, tlie mental elenients used by the law, no matter low they are couclied, reflect policy decisions about wliat types of people deserve punishment, which human frailties are to be considered in assessing guilt, and low much protection society deniands. ${ }^{10}$

By contrast, psycliiatry, as a science, seeks to discover the roots of human beliavior and, as a branch of medicine, to find cures for mental illness. This quest is not guided by the social policy concerns of the criminal law. If psychiatry is used as a tool, it will be an unpredictable tool, one whose analyses of factually identical cases may vary as psychiatry progresses scientifically. ${ }^{11}$

The fundamentally different natures of the disciphines could cause serious difficulties for the legal system if psychiatric concepts were directly incorporated into legal ones. There might be no problem if the law were to make a policy decision to base adjudication on psycliatric analyses. However, it seems more likely that psychiatric concepts would be used merely as convenient tools to achieve a particular balance between protection and toleration. If so, developments in psychiatry could force inconsistent legal results, impairing the law's underlying policy goals.

Furtliermore, disruption could occur if legal terms were gradually to take on psycliatric content. For example, if concepts sucli as "malice" or "premeditation" were to evolve from essentially conclusory descriptions of the evilness of wrongdoers into tests for actual mental events, then the nature of the inquiry would become increasingly technical. It would cliange from "Is this the sort of person wlio deserves societal condemnation?" to "Is this tlie sort of person wlio was capable of entertain-

10. The results of these policy decisions are seen in the criminal law. For example, the killer who can successfully clain self-defense is set free, while tlie person found not guilty by reason of insanity will alınost certainly be comınitted. See W. LAFAVE \& A. ScoTT, supra note 5, \$\$ 47-57 (varieties of justification and excuse); id. $\S 41$ (procedures following a verdict of not guilty by reason of insanity). Society does not regard coinmitinent of the insane as punishment. As the drafters of the Model Penal Code aptly observed, society views the insane as unsuitable for punishment. Model Penal Code $\$ 4.01$ comment at 156-57 (Tent. Draft No. 4, 1955). The differential treatment of the insane individual and the individual acting in self-defense makes good common sense and good policy sense. The individual who killed in self-defense presents no danger to society, and has not violated social norms. The insane individual, however, is perceived as a "ticking bomb." Whatever their intrinsic merit, these perceptions represent an accommodation between protection and toleration in the law.

11. The volatility of psychiatry may be greater than that of other scientific fields, given the diversity of its theoretical approaches. See, e.g., T. KUHN, ThE STRUCTURE OF Sc1ENTIFIC REvoLUTIONS at $x$ (1962) (unlike physical scientists, beliavioral scientists constantly disagree over fundamental concepts in their fields); Diamond, supra note 8, at 115; Livermore \& Meehl, The Virtues of M'Naghten, 51 MiNN. L. REv. 789, 811 n.68 (1967) (briefly describing psychoanalytic, psychoinetric, and learning-theoretical approaches to the analysis of behavior and inental life). 
ing a certain kind of thought?" and "Did he do so at the time of his act?" Psychiatrists, not judges and juries, would be the ones with the training and skill to make those determinations. ${ }^{12}$ While the law could retain the power to overrule its experts, the factual determinations upon which the judgment would turn would be increasingly found in another discipline.

The volatility of psychiatric concepts creates a further problem which goes to the integrity of the law's concepts. If, for example, murder required a set of specific mental events and psychiatrists determined that certain of these events were not, in fact, psychiatrically valid, then the conceptual basis of the law's definition of murder would be called into question. One way to resolve the problem would be for psychiatry to provide ever more sophisticated operational meanings for legal terms. ${ }^{13}$ However, if the law must abandon or change its concepts each time there is a change in an underlying discipline, then it is in the unacceptable position of having its analyses governed by that discipline, again losing policy control. ${ }^{14}$ The law could insist on keeping its concepts constant as psychiatry advanced. But then it would be basing crucial decisions, sometimes involving life and death, on subtle distinctions that are often not borne out in what appears to be the inost relevant discipline. Thus, it is very difficult to see how a legal analysis concerning actual mental

12. To a large extent, the law has been able to dodge this bullet by pointing to what it sees as the primitiveness of psychiatric theory as epitomized by the very variety of theories. Professor Kadish characterizes this position as maintaining that "psychiatric testimony is worth little-it is the softest of the soft sciences, psychiatrists disagree on key concepts and their conclusions and analyses turn on their own value judgments." Kadish, supra note 2, at 277. Soine, however, argue that psychiatry has reached a point where it can be truly useful in legal analysis. See Bonnie \& Slogobim, The Role of Mental Health Professionals in the Criminal Process: The Case for Informed Speculation, 66 VA. L. REv. 427 (1980) (arguing that the law will become increasingly concerned with subjeetive factors in identifying crime and determining punishınent, and that psyehiatry, for all its flaws, can be productively employed by the law in making such determinations).

13. This approach is reflected in Dr. Diamond's provision of an analysis of the "psychological equivalents" of "malice aforethought" in People v. Gorshen, 51 Cal. 2d 716, 723, 336 P.2d 492, 496 (1959), a leading California diminished capacity case.

14. This problem does not arise only in the context of crininal law. Under the doctrine of Roe v. Wade, 410 U.S. 113 (1973), the state can regulate abortions for two purposes: after the first trintester to protect the mother, simce after that point the risks attendant on abortion arc greater than those associated with childbirth; and during the third trimester to protect a viable fetus. Justice O'Connor recently noted two closely related flaws in this formulation. First:

The Roe framework . . . is clearly on a collision course with itself. As the medical risks of various abortion procedures deercase, the point at which the State niay regulate for rcasons of maternal health is moved further forward to actual childbirth. As medical science becomes better able to provide for the separate existence of the fetus, the point of viability is moved further back toward conception.

City of Akron v. Akron Center for Reproductive Health, Inc., 103 S. Ct. 2481, 2507 (1983) (O'Comior, J., dissentimg).

The second flaw involves a problein logieally similar to that discussed in the text: the possibility that legal standards-in the abortion context, constitutional ones-inight change "every time the American College of Obstetricians and Gynecologists . . . or similar group revises its views about what is and what is not appropriate medieal procedure." Id. at 2506. 
states can proceed with integrity unless the states of inind posited by it make psychiatric sense. Moreover, excluding psychiatric evidence might cause probleins within the law itself. Some have even suggested that the adınission of psychiatric evidence on the issue of presence or absence of mental elements of a crime is constitutionally required. ${ }^{15}$

On the other hand, if legal and psychiatric concepts are less closely related-for example, if psychiatric concepts only advise legal conceptsless disruption in one conceptual system should result as changes occur in the other. For example, when the factfinder must decide whether or not a person acted reasonably, or whether a reasonable person would have been provoked, he applies community standards to all the circumstances of the case. Simce these inquiries are not searches for specific psychological content, changes in psychiatric analysis would not have so profound an impact on the concepts used by the law, even though the information supphed by the psychiatrist may be helpful in applying the legal concepts.

Finally, aside from the probleins of conceptual disruption engendered by a close connection between legal and psychiatric concepts, the law may fail to obtain the information it wants if it speaks in terms of mental events. If the law asks highly technical questions that presuppose outmoded psychiatric theories, it may request information that a competent psychiatrist is unable to provide. Even if the problem were less severe, stilted legal questions might produce less information about the causes of the defendant's behavior than the law intended to elicit. ${ }^{16}$

15. See, e.g., Note, The Relevance of Innocence: Proposition 8 and the Diminished Capacity Defense, 71 CALIF. L. REV. 1197 (1983) (challenging the constitutionality of outlawing the diminished capacity defense on two grounds: first, as violating the right to present rehable and relevant evidence; and second, as failing to maintain the presumption of innocence) [hereinafter cited as Note, The Relevance of Innocence]; see also Note, Restricting the Admission of Psychiatric Testimony on a Defendant's Mental State: Wisconsin's Steele Curtain, 1981 W1S. L. REv. 733 (arguing that the refusal to admit psychiatric testimony to negate specific intent may violate the 6 th and 14 th ainendments by disallowing evidence needed to rebut the accusation).

16. Consider an analogy. Suppose the law asked astronomers whether there had been an eclipse of the sun over Katmandu on July 12, 1794. Modern astronomy is conceptually stable as regards the heliocentric nature of the solar system and the predictability of planetary motion. Thus, it probably does not matter whether the law asks: "Did the moon in its revolution about the earth coine between Katmandu and the sun along the line conneetimg those two locations on July 12, 1794?" or "Did something occur in the sky-other than clouds and the like-to darken the sky above Katmandu on July 12, 1794?' But what if astronomy were in conceptual ferment? What if there were a moon-contered theory or a cosmology that attributed lunar echipses to a clumsy water carrier spilling his gourd (the moon) on the fire of the sun. Now, an adherent of the moon-centered theory could handle either of the above questions easily enough; but for a water-carrier theorist, the first question makes no sense. The second question, however, would probably elicit the requisite information.

The point is that the law risks asking foolish questions when it tries to speak in astronomy's terms or in terms similar to those used by astronomers; the information it wants can be obtained by asking nontechnical questions. Worse, if the law chose to ask the first of the two questions above, as astronomy advanced from the primitive hehocentric view through the more advaneed lunacentric 
This Comment does not, therefore, suggest that psychiatry be used to rework the meanings of legal terms. Rather, it argues that effective use of psychiatric information by the law is most likely if the law does not attempt to make fine distinctions of the sort that psychiatrists make.

\section{The Impact of Conceptual Change: $A$ View from the Sciences}

How will the legal community and the public react to psychiatric information that is logically probative ${ }^{17}$ when its use appears to give psychiatrists effective control of legal decisionmaking or threatens to undermime the law's goal of societal protection? Professor Kuhn's analysis of how scientists respond to developments that challenge existing theoretical paradigms provides a clue.

Kuhn divides the process of scientific change into three phases: normal science, crisis, and revolution. ${ }^{18}$ In the "normal science" period, the main scientific activity is the solution of "puzzles" within a generally accepted paradigm. Durmg this time, most competent researchers agree on theoretical concepts, worthwhile research probleins, and research strategies. ${ }^{19}$ Even during a period of normal science, there may be "anomalies," experimental or observational outcomes that do not fit readily within the paradigm. Yet scientists do not attempt to resolve every anomaly immediately-if they did, they would be constantly distracted and would never get any serious work done on the puzzles that lie at the heart of normal science research. ${ }^{20}$ Rather, an anoinaly may be shelved for the time being or accounted for by ad hoc adjustments to the paradigm.

However, anomalies may become so serious that "insecurity is generated by the persistent failure of the puzzles of normal science to come out as they should." 21 When this occurs, the science enters the crisis phase. The key is whether or not "an anomaly comes to seem more than just another puzzle of normal science."22 Kuhn argues that even serious anomalies do not autoinatically cause abandoninent of the old paradigm. Instead, they make it vulnerable to replacement by a better one in the

view to the ultimately correct water-carrier view, the law's query would change from being an entirely apt one to one which a competent astronomer might be unable to answer coherently. The second of the two questions, however, would continue to be answerable as knowledge advanced; its very simplicity and naivete make it robust.

17. For examples of the use of "logical" in this sense, see infra note 60 .

18. See generally T. KUHN, supra note 11. Although there are other ways to analyze the nature of scientific change, Professor Kuhn provides a particularly useful framework.

19. Id. at 23-34 (discussing normal science); id. at 35-42 (discussing the puzzle-solving aspects of normal science). The failure of a puzzle to yield to research efforts is generally taken to reflect on the skill of the researcher, not on the validity of the paradigm.

20. Id. at 82 .

21. Id. at 68 .

22. Id. at 82 . 
"revolutionary" phase. In other words, a paradigm will not be abandoned for nothing, only for something better. ${ }^{23}$

Kuhn's analysis is as much about the psychology of scientists as it is about science. But scientists are not a species apart. If he is even approximately correct that scientists will not allow anomahes to cause them to abandon an imperfect but generally productive paradigm absent something better, we may expect similar reactions in other fields, including the law. ${ }^{24}$ Legal decisionmakers may be quite willing to use psychiatric information as a problem-solving tool within their paradigm. However, Kuhn's analysis would predict "paradigm-preserving responses" where psychiatry threatens (or appears to threaten) the ability of the law to satisfy its social role.

II

Psychiatric KNOWledge AND the LAW: SOME EXAMPLES

This Part examines three uses of psychiatric information in the law. Together, they support the thesis that the legal cominunity will accept psychiatric information when it aids legal problem solving. However, the legal community will restrict its use when it appears to threaten the law's protective function or to place decisionmaking power outside of the legal community. This will occur whether or not the logic of the situation suggests that psychiatric information should be useful. The paradigmpreserving reaction will be sharper as legal concepts beconie more similar to psychiatric ones.

23. Id. at 77 .

24. Examples of paradigm-preserving responses have appeared in the law for centuries. See, e.g., Langbein, Torture and Plea Bargaining, 46 U. CHI. L. REV. 3 (1978) (arguing that the voluntary confession rule, introduced by the church in the 13th century with the termination of trial by ordeal, led to the use of torture to elicit "voluntary" confessions, lest no conviction be possible, and that plea bargaining represents a contemporary analogue that allows the law to circumvent impractically rigorous formal restrictions). Similarly, the Hebrew courts einployed extremely strict rules of evidence, see A. Steinsaltz, The Essential Talmud 166-70 (1976) (only eyewitness testimony, verified by two men of good character, was admissible, and before a man could be executed there had to be unmistakable proof that he had been explicitly cautioned about the nature and consequences of the act he was about to commit and had understood the warning by saying "I know and I take it upon myself"). The Hebrew courts also had strict rules of criminal procedure. See id. (a member of the panel of judges could not change his mind having once spoken in favor of the defendant, but a statement against the defendant could be retracted). However, the system included two adaptations designed to protect the public. See id. (the monarch could establish special courts that did not operate under these restrictions or the religious court could sit as an admimstrative tribunal and wield broad power to turn aside threats to order, morals, or religious observances).

These examples are interesting because they highlight the accommodation of cherished values (characterized by extreme procedural rigor) with the nced to protect society. The use of torture to achieve this accommodation is particularly telling because, despite constant criticism, torture continued to be used until reformers replaced the system of evidence that had made its use necessary to obtain convictions. Langbein, supra, at 7-8. 
The first example concerns the judicial response to expert testimony on the "battered woman syndrome," a psychiatric explanation for the violent reactions of physically abused women. Many courts have been receptive to such testimony. It does not appear to supplant the legal inquiry with psychiatric conclusions. Rather, it aids informed application of the legal policy to show tolerance to those who have responded reasonably to a reasonable fear.

The second example reviews the use of well-known and accepted "insanity" tests to deal with the problem of extreme mental deficiency. This approach appears to threaten no disruption of the policy balance between societal protection and consideration of the individual, because it merely applies an existing solution to a "new" class of cases.

The third example concerns the diminished capacity defense, in which the defendant seeks to show that he was incapable of possessing a mental state required for a particular crime. This defense leads to a detailed examination of the defendant's psychological processes. Many courts have sharply restricted it for fear that societal protection will be sacrificed as psychiatry exerts increasing influence on legal decisions.

\section{A. Self-Defense and the "Battered Woman Syndrome"}

\section{Overview of the Syndrome and the Response of the Courts}

Recently, women asserting self-defense claims have offered expert testimony concerning the "battered woman syndrome."25 This testimony is offered to help the jury understand the effects of repeated battering, why the defendant reacted violently, and why she did not leave her batterer. By explaiming these matters, an expert can help the jury to determine whether or not the woinan responded reasonably to a reasonable fear.

25. For a discussion of the syndrome, see Walker, Thyfault \& Browne, Beyond the Juror's Ken: Battered Women, 7 VT. L. REV. 1 (1982), upon which the following explanation is based. The battered woman is usually paired with a mate who was reared in an environment in which physical abuse was common. Typically, she is socially isolated by, financially dependent on, and sexually abused by him. He has threatened to harm her if she leaves, a threat upon which he may well make good. This pattern of abuse and dependency may lead to a condition of "learned helplessness" in which "[a] battered woman often believes that the batterer is omnipotent, that no one can help her, and thus she himits the number of responses she feels are possible or safe to make." Id. at 8-9. At some point, the situation becomes intolerable, usually because of some extreme episode such as an increase in the frequency or severity of battering or molestation of the children. The woman may then desperately launch what is probably her first physical counterattack against her abuser. Even if this counterattack is plainly of lethal proportions, she may not realize its seriousness until much later. Moreover, the counterattack may occur when the batterer's guard is down-a time when the danger seems to have deereased and flight appears practical.

For a general discussion of defense theories employing the battercd woman syndrome and their likelihood of success, see Comment, The Battered Spouse Syndrome as a Defense to a Homicide Charge Under the Pennsylvania Crimes Code, 26 VILL. L. REv. 105 (1980). 
There has been a mixed judicial response on the admissibility of expert testimony concerning the battered woman syndrome. The case of Ibn-Tamas v. United States ${ }^{26}$ illustrates one court's response. For several years, Beverly Ibn-Tamas had been beaten by her husband. Shortly after one such beating, she shot and killed him, ${ }^{27}$ and was tried for murder. The trial court was found to have "erred as a matter of law" in excluding evidence concerning the syndrome on the ground that it would invade the province of the jury. ${ }^{28}$ The appellate court found that such testimony would not determine the ultimate issue of the defendant's actual and reasonable belief in her danger. Instead, it would provide information otherwise beyond the ken of the jury, that the jury could use in making this determination itself. ${ }^{29}$

The appellate court ruled that expert testimony was potentially admissible if it would "provide a relevant insight which the jury otherwise could not gain in evaluating appellant's self-defense testimony about her relationship with her husband." 30 According to the court, the proffered testimony might enhance the plausibility of Ibn-Tamas' testimony and give credence to her claim that she perceived herself to be in imminent danger. ${ }^{31}$ The only acceptable reasons for excluding such testimony were inadequate expert qualifications or a state of scientific development so primitive that an opinion could not reasonably be advanced. ${ }^{32}$

Several jurisdictions now recognize the potential value of testimony on the battered woman syndrome to illuminate the inquiry into the reasonableness of the defendant's fear. ${ }^{33}$ At least one jurisdiction holds that

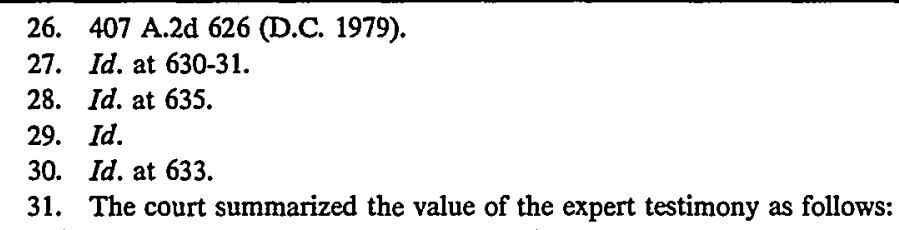

[T] he defense proffered Dr. Walker's testimony to (1) inform the jury that there is an identifiable class of persons who can be characterized as "battered women," (2) explain why the mentality and behavior of such women are at variance with the ordinary lay perception of how someone would be likely to react to a spouse who is a batterer, and thus (3) provide a basis from which the jury could understand why Mrs. Ibn-Tamas perceived herself in imminent danger at the time of the shooting.

Id. at 634.

32. Id. at 633,640 . On reinand, the trial court found that the expert's scientific methodology was not sufficiently well-accepted to justify adinission. This determination was upheld on appeal. Ibn-Tamas v. United States, 455 A.2d 893, 894 (D.C. 1983).

33. See, e.g., Hawthorne v. State, 408 So. 2d 801, 806-07 (Fla. Dist. Ct. App. 1982) (per curiam) (although expressing doubts about the scientific validity of the syndrone, the court clearly saw its conceptual utility, noting: "It is precisely because a jury would not understand why appellant would remain in the environment that the expert testimony would have aided them in evaluating the case."); Sinith v. State, 247 Ga. 612, 619-20, 277 S.E.2d 678, 683 (1981) (the reasons why a battered woman would not fiee and the nature and extent of her fear are conclusions that a jury of laypersons would not ordinarily draw and are, therefore, suitable topics for expert testimony); State v. Kelly, 33 Wash. App. 541, 544, 655 P.2d 1202, 1203 (1982) (dictum) (battered woman syndroine 
a history of abuse should be considered in determining whether the prosecution has met its burden of showing the unreasonableness of the defendant's belief in imminent danger. ${ }^{34}$ As in Ibn-Tamas, these courts realize that consideration of the effects of repeated beatings is useful in assessing the reasonableness of a violent reaction.

In addition, one court has determined that evidence concerning the long-term effects of battering may be used in a "heat of passion" defense to reduce a charge of murder to manslaughter. ${ }^{35}$ Thus, such evidence may be applied beyond the self-defense plea to help the factfinder determine whether the defendant responded to provocation that would have aroused the heat of passion in an ordinary person.

Testimony has been rejected when courts have felt that research was not sufficiently advanced to provide accurate information ${ }^{36}$ or that the jury was capable of understanding the effects of battering without expert explanation. ${ }^{37}$ But, at least at the appellate level, none of these cases reveals a fear that psychiatrists will grab decisionmaking authority or that the introduction of such evidence will endanger society.

\section{Evidence Concerning the Battered Woman Syndrome in Self-Defense Cases and the Protective Function of the Law}

The self-defense plea is a classic example of a legal policy decision to lift responsibility in some situations, but not in others. The plea is designed to aid the person who defends himself in a truly desperate situation, not the person with a hair-trigger temper or an exaggerated sense of

does not justify killing, but it does help to establish a character trait that is useful to the jury in assessing the woman's impression of danger and the reasonableness of her fear of imminent harm), rev'd on other'grounds, 102 Wash. 2d 188, 685 P.2d 564 (1984).

34. Co'mmonwealth v. Watson, $444 \mathrm{~Pa} .467,472,431$ A.2d 949, 952 (1981). This case did not involve an attempt to introduce an expert witness, but it did discuss the factfinder's need to understand why a battered woinan unght not leave her batterer and why, following a long period of abuse, she might reach the "breaking poimt" and react violently.

35. State v. Felton, 110 Wis. $2 d$ 485, 329 N.W.2d 161 (1983). In Felton, a woman who had been beaten over a period of more than twenty years shot her sleeping husband following a particularly serious quarrel and was convicted of second-degree inurder. The court felt that the case was arguably withm the Wisconsin rule that allows consideration of the cumulative effect of beatings and humiliation, even though "the action of [the deceased] in the last few minutes before the shooting .. . would not be sufficient to produce the required degree of disturbance in an ordinarily constituted person.' "Id. at 510, 329 N.W.2d at 172-73 (quoting State v. Hoyt, 21 Wis. 2d 284, 291, 128 N.W.2d 645, 649 (1964)).

36. Ibn-Tamas v. United States, 455 A.2d 893 (D.C. 1983); State v. Thomas, 66 Ohio St. 2d 518, 423 N.E.2d 137 (1981); Buhrle v. State, 627 P.2d 1374, 1376-78 (Wyo. 1981).

37. State v. Griffiths, 101 Idaho 163, 165, 610 P.2d 522, 524 (1980), overruled on other grounds by State v. LePage, 102 Idaho 387, 396, 630 P.2d 679, 683-89 (1981); State v. Thomas, 66 Ohio St. 2d 518, 521, 423 N.E.2d 137, 140 (1981). A court's refusal to accept testimony concerning the battered woman syndrome inay also partly reflect a fear of " 'the feminist and the murderer," "eaeh of whom " "tests society's estabhished boundaries." " Walker, Thyfault \& Browne, supra note 25, at 2 (quoting A. JONES, WOMEN WHO KILL (1980)). However, the dominant reasons for rejection are probably not so pohtieal. 
peril. Yet, an exceptionally timid person may in fact feel as threatened in an innocuous situation as a sturdier person feels in a truly dangerous one. The distinction turns on the objective "reasonableness" of the reaction, a standard that belongs, not to the psychiatric world, but to the lay one. The use of such standards allows psychiatric evidence to aid the factfinder in making his determination without nnaking the decision for him. ${ }^{38}$

It is important to note that, when using evidence of the battered woman syndrome, it is unnecessary to redefine legal terms or to ask those testifying to identify the psychological analogues of, for example, "fear" or "reasonableness." Instead, the testimony inerely enriches the evidence used by the factinder to decide whether the defendant's action qualified as a "reasonable response," thus eliminating or lessening the societal sanction.

Whether or not the psychological theories underlying the battered woman syndrome endure or are replaced by more advanced theories is largely irrelevant for legal purposes. The questions asked-"Was she really afraid for her life?" "Was such fear reasonable?" "Did she behave reasonably in light of the fear?"-remain constant. The questions do not require subtle psychological analyses. Although the information a psychiatrist provides may be highly technical and may inake fine distinctions among subjective mental states, the law does not look to the expert testimony to provide esoteric information that largely determines the defendant's status relative to complex, quasi-psychiatric legal concepts. Rather, the value of the testimony derives from its ability to illuminate for the factfinder the impact of events outside normal experience. It is the broad societal sense of what is reasonable that is ultimately decisive. ${ }^{39}$

38. But see Model PENAL CODE $§ 3.04$ comment at 14-15 (Tent. Draft No. 8, 1958) (urging the adoption of a subjective test for the necessity of the use of force). Under the present analysis, adoption of such an approach might be a serious mistake. As psychiatry advances, it may prove that subjective belief in the necessity of a forceful response is very common. If so, a subjective standard might threaten to undermine the protective function of the law by forcing the release of many whom it would be in the interest of public safety to restrain. Possible reactions to this might be to resist the admission of psychiatric testimony or to develop ever finer tests to limit the impact of otherwise exculpatory psychiatric evidence.

39. The Patty Hearst ease suggests that evidence of the effect of traunatic experiences may be more readily admissible when the evidence is not closely tied to specific, legally identified mental states.

[T] he Government's arguinent is that since in this Circuit the crime of bank robbery . . . has been held not to require proof of a specific, but only a general, intent, . . . expert testimony offered to show that the defendant acted with a reduced mental capacity is irrelevant . . . . Without disputing the soundness of the premise on which this argument rests, the Court will sinply point out that in this case the expert testimony is not being offered to prove diminished capacity sufficient to negatc specific intent.

United States v. Hearst, 412 F. Supp. 889, 890 (N.D. Cal. 1976) (citations omitted).

The court went on to admit expert testimony "to explain the effects kidnapping, prolonged incarceration, and psychological and physical abuse may have had on the defendant's inental state at 
The purpose of expert testimony, then, should be to explain. Explanation of behavior is not exculpatory per se, for if it were, all acts would become permissible as they were explained. ${ }^{40}$ Lust, revenge, and jealousy are recognized as motives that serve to explain, but not to exculpate. ${ }^{41}$ No amount of testimony about the syndrome, or about an individual suffermg from it, will control the determination of whether or not that individual's reaction in a given situation was "reasonable." ${ }^{22}$ Because this evidence merely expands the information available without appearing to dictate the outcome, it presents little threat of disrupting the policies that underlie the law. Insofar as consideration of such evidence changes societal thinking, the change will come not by overwhelming the factfinder, but by affecting the perceptions of society, and thereby effecting changes in social policy. In Kuhırian terms, the information from psychiatry in these cases enters primarily as a problem-solving tool, not as a source of anomaly that may disrupt the problem-solving ability of the law.

\section{B. Extreme Mental Deficiency: Applying Existing Standards to New Conditions}

Some persons are so profoundly mentally retarded that society has

the time of the robbery, insofar as such mental state is relevant to the asserted defense of coercion or duress." Id. This suggests that the court might have considered excluding the evidence had its admission been predicated on its relation to particular types of intent. In other words, as legal and psychiatric discourses converge, courts will have to pay increased attention to the relationship between the elements used in psychiatric analyses and the mental elements identified as pertinent by the law. Indeed, the limitation of psychiatric testimony to certain elements may be one of the chief paradigm-preserving reactions triggered when judges feel overwhelmed by psychiatric testimony. See infra Part II, Seetion $C$.

40. Cf. Louisell \& Diamond, supra note 8, at 232:

[T]he law's acknowledgement of determinants of crime depends largely upon society's goals in the administration of criminal justice. It seems reasonable to hope that if psychiatry and other behavioral sciences increasingly validate particular determinants beyond the control of the offender as causes of criminal conduct, society and hence the law may be educated to a correspondingly growing willingness (i) to diminish the infliction of pain as an act of institutionalized social revenge upon the evildoer, for if "to know all is to forgive all," increasing knowledge of the determinants should aid us to hold in leash the aggressive and retributive instincts; (ii) to pretermit the essentially theological function of adjudicating ultimate moral responsibility, concentrating its limited human intelligence and energies on rehabilitating the offender and restoring him to the community while constructing as best it can the social defenses against crime.

While advancing the hope that better understanding will lead to more humane treatment, this analysis does not suggest that explanation requires any particular type of treatment. Plainly, the law and its policies control what to make of such improved explanatory power.

41. Id. at 226-28. Similarly, the law builds constraints around the explanations that it does accept. For example, a person who is genuinely provoked must take no longer to "cool" than would a reasonable person, and the courts do not always recognize that passions may be rekindled and the cooling period begun anew. W. LAFAVE \& A. ScoTr, supra note 5, $\$ 76$, at 579-80.

42. Some courts that accept psychiatric evidence in assessing a self-defense plea do not regard it as relevant to the reasonableness element. See, e.g., Commonwealth v. Light, $458 \mathrm{~Pa} .328,336$, 326 A.2d 288, 293 (1974). 
determined that they should not be held responsible for their misdeeds. ${ }^{43}$ They, like the insane, may be thought of as falling into a category "so extreme that to the ordinary man the exculpation of the persons it encompasses bespeaks no weakness in the law. He does not identify such persons and hinself; they are a world apart." 44 But while it seems intuitively clear that such persons should be accorded special consideration, the issue arises as to how the law should approach the problen doctrinally.

\section{Use of the Insanity Analysis: The Obvious Answer}

A simple solution to the puzzle of how to deal with the extremely mentally retarded wrongdoer is to employ the jurisdiction's insanity defense, whatever that may be. If the jurisdiction uses a statute that already covers "mental disease or defect," as does the Model Penal Code, ${ }^{45}$ then there is no problem to be solved. If the statute refers only to "mental disease," then courts may have to generalize, but the required generalization is modest. Many courts interpret the "disease of the mind" standard under the M'Naghten rule ${ }^{46}$ to imclude extreme mental

43. Consider the following hypothetical posed by Professors Livermore and Meehl:

Defendant, an adult living at home with his parents, is a mentally deficient individual with an IQ in the imbecile range. He has been watching some neighbor boys play cops and robbers with capguns, and upor finding a loaded revolver in the glove compartinent of his father's car, he shoots and kills one of the neighbor boys. The patient's intellect is such that he does not discriminate between a capgun and a revolver, does not understand the meaning of death, does not know the difference between a television actor who falls down upon being shot and one of the neighbor boys who falls down pretending to be killed, and so forth. While in jail he asks whether the slain person will come to visit hin. He shows no coinprehension of what he has done or why he is involved with the police and is thoroughly baffled by the whole proceeding.

Livermore \& Meehl, supra note 11, at 833-34 (1967).

44. Model Penal Code $\S 4.01$ cominent at 156-57 (Tent. Draft No. 4, 1955).

45. The Model Penal Code test states:

(1) A person is not responsible for criminal conduct if at the time of such conduct as a result of mental disease or defect he lacks substantial capacity either to appreciate the criminality [wrongfulness] of his conduct or to conform his conduct to the requireinents of the law.

(2) As used in this Article, the terms "mental disease or defect" do not include an abnormality manifested only by repeated criminal or otherwise anti-social conduct.

Id. $\$ 4.01$ (Proposed Official Draft 1962).

This approach is consistent with the perspective that the drafters of the Model Penal Code brought to their task:

What is involved . . . is the drawing of a line between [condemnation] by conviction, with resultant sanctions in which there is inescapably a punitive ingredient . . . and modes of disposition in which that ingredient is absent, even though restraint may be involved. . . . [T] $]$ he problem is to discriminate between the cases where a punitive-correctional disposition is appropriate and those in which a medical-custodial disposition is the only kind that the law should allow.

Id. $\$ 4.01$ cominent at 156 (Tent. Draft No. 4, 1955).

There is no attempt to draw extremely precise lines between mental states in this portion of the Model Penal Code and coinmentary.

46. The rule as given by the House of Lords is: 
deficiency. ${ }^{47}$ With this generahization behind it, the court may proceed to the analysis of mental ability. ${ }^{48}$

A New Jersey case, State v. Huff, ${ }^{49}$ decided at a time when that state used the "mental disease" form of the M'Naghten rule, illustrates this approach. The thirty-eight-year-old Huff, who had a mental age of eight years, killed his wife by pushing her down a set of stairs. ${ }^{50}$ Although noting that the issue was not before it, the court indicated that evidence of mental age does not transform a mentally retarded adult into an infant for legal purposes. Rather, "the test is his appreciation of the nature and the quality of his act and the difference between right and wrong in its commission." 1

The mam point for this analysis is that a solution to the "puzzle" of the mentally retarded offender is so readily available within the existing paradigm that it is hardly a puzzle at all. Whether the person falls into

[T]o establish a defence on the ground of insanity, it must be clearly proved that, at the time of the committing of the act, the party aceused was labouring under such a defect of reason, from disease of the mind, as not to know the nature and quality of the act he was doing; or, if he did know it, that he did not know he was doing what was wrong. M'Naghten's Case, 8 Eng. Rep. 718, 722 (1843).

47. The possibility of using the M'Naghten test was suggested by Livermore \& Meehl, supra note 11, at 834. Professor Pieski also discussed the test with regard to subnormal mentality, in Pieski, Subnormality as a Defense in the Criminal Law, 15 VAND. L. REV. 769, 776 (1962). Professor Pieski noted that subnormal mentality may negate either the actus reus, since "[w]here there is no rational human conduct there is no crime," $i d$., or the mens rea by preventing the defendant's understanding of the wrongfulness of his conduct (one prong of the M'Naghten test), id. at 777.

48. This approach is the majority rule in M'Naghten jurisdictions. Pieski, supra note 47, at 781-84. Professor Pieski also identified two minority rules. He cited two cases for the rule that restricts M'Naghten to insanity: Stewart v. State, 233 Ark. 458, 461, 345 S.W.2d 472, 474 (1961) ("appellant was mentally dull but . . . without psychosis and knew right from wrong. . . . That one has a mind below normal does not exempt him from punishment for his criminal act"); and State v. Schlaps, 78 Mont. 560, 578, 254 P. 858, 862 (1927) (distinguishing between the sane and the insane, but not between sane defendants by degree of intelligence). Pieski, supra note 47, at 784 .

The seeond minority rule cited by Professor Pieski excludes "idiots" from the class of people capable of committing crimes. See, e.g., Cal. Penal Code $\$ 26$ (West Supp. 1985). Before 1981, the statute also excluded "lunatics and insane persons." Id. $§ 26$ (West 1970). In practice, courts applied the M'Naghten analysis. See, e.g., People v. Oxnam, 170 Cal. 211, 213, 149 P. 165, 166 (1915); People v. Fisher, 49 Cal. App. 3d 174, 177-78, 122 Cal. Rptr. 366, 368-69 (1975); see also Pieski, supra note 47 , at 785 .

In People v. Drew, 22 Cal. 3d 333, 583 P.2d 1318, 149 Cal. Rptr. 275 (1978), the California Supreme Court adopted the Model Penal Code test for judging mentally diseased defendants. To maintain consistency, it also adopted the Model Penal Code test for judging the mentally defective defendant. In re Ramon M., 22 Cal. 3d 419, 584 P.2d 524, 149 Cal. Rptr. 387 (1978). Thus, while the specific rule changed, the principle of applying a consistent standard to the two types of defendants remained. However, at least as to insanity, a version of the M'Naghten test was adopted by a ballot measure, Proposition 8, approved by the voters in 1982. Sec Cal. Penal CoDE $\S 25$ (b) (West Supp. 1985).

49. 14 N.J. 240,102 A.2d 8 (1954).

50. Id. at $250,102 \mathrm{~A} .2 \mathrm{~d}$ at 13 .

51. Id. Interestingly, the $H u f f$ court based its test in part on a much earlier case that held that "deficiency of intellect is a species of insanity." State v. Schilling, 95 N.J.L. 145, 148, 112 A. 400, 402 (1920). 
the "extreme" category because of insanity or mental retardation is, in the abstract, a modest distinction. The same basic paradigm works equally well for either category. ${ }^{52}$

\section{The Success of the Insanity Analysis and the Difficulty with a Reform Proposal}

The New Jersey approach neither impairs the ability of the state to protect its citizens nor introduces any new conceptual problems in applying the law and effecting social pohicy. This is so for several reasons. First, the possibility of the commitment of those found not guilty under an insanity analysis provides a ready means to protect society from the truly dangerous. Second, since insanity tests have already been applied to the mentally ill, the law has experience in dealing with the conceptual difficulties they present. Third, there are few, if any, probleins in allocating effective control over critical determinations between psychiatry and the law that do not also arise in dealing with the insane. Thus, the policy balances that have been struck in dealing with the insane simply carry over to the mentally retarded.

Professor Pieski has suggested an alternative approach which would require closer attention to the degree of impairment. ${ }^{53}$ This approach calls for a "shiding scale" of presumption of capacity to act, based on the defendant's degree of impairment. The idea is that "various forms of subnormality should have a different probative effect on the presumption of capacity to act or to recogmize one's act as unlawful (wrongful)."54 Application of this scale would allow the court to reduce responsibility and, with it, tlie grade of the offense or the pumishment imposed. ${ }^{55}$

Drawn broadly to reflect a social desire to mitigate an overly harsli result, such a rule could result in a judicial response sensitive to the relative incapacity of the offender. The proposed rule imight also encourage increasing judicial sensitivity to inental deficiency as psychiatry advances. However, an attempt at much greater precision could lead to serious conflicts between psychiatry and the law. If the law attempts to identify several scalar points, perhaps by relying on intelligence measures to trigger presumptions of capability, ${ }^{56}$ it will have adopted a particular type of psychiatric formulation that essentially determines the legal

52. The focus in the New Jersey rule on whether or not the individual in fact knew the nature and quality of his act performs the same function as the "substantial capacity . . . to conform" requireinent in Model Penal Code $\S 4.01$. See supra note 45. In either case, the inere presence of a condition affecting mental functioning is not enough to exculpate: the mental condition must also be shown to have specific effects on the defendant's cognitive functions or volitional control.

53. Pieski, supra note 47 , at $786-94$.

54. Id. at 788 .

55. Id. at 786-94.

56. See id. 
response. This will require finer distinctions and more precise rules. As the rules become inore precise, they will increasingly depend on the types of technical analyses at which psychiatrists are superior. However, the law will have chosen its scalar points to fulfill certain of its own policy objectives. Thus, the law will be engaged in a technical inquiry designed to achieve a substantive pohicy, but with the key deterinination falling in another discipline.

Moreover, the points on the scale would presumably be selected in accordance with the current state of psychiatric knowledge about extreme mental deficiency. But psychiatry is not static and frequently revises its formulations. If the law resists corresponding change in order to avoid impairment of its policy objectives, it risks becoming locked into a system that may rapidly become outdated. The law may find itself asking psychiatrists to testify about distinctions that no longer make psychiatric sense. Thus, a system that started out to be "advanced" would become archaic as change occurs in the underlying discipline of psychiatry. ${ }^{57}$

\section{Diminished Capacity and the Problem of Sophistication}

The analytical development of the diminished capacity defense typifies the problems that occur when legal and psychiatric discourses converge. The defense focuses attention on the specific mental elements that must be shown to justify conviction. This attention to inental state tends to emphasize the conceptual importance of psychiatric evidence for legal decisions. As a result, psychiatry may appear to dominate legal decisionmaking and mterfere with the ability of the law to achieve the policy goals for which it was established. Faced with this potential disruption, legal decisionmakers behave rather like scientists faced with disruption of an imperfect but functioming paradigm: they find ways to limit the defense and to preserve the ability of law to achieve its policy goals.

57. Similar problems would probably result from the "restatement" of the M'Naghten test suggested by Professors Livermore and Meehl:

The defendant will be excused if at the time of the criminal act he had a mental disease or defect which imcluded among its symptoms or consequences an impairment in one or more of the psychological functions requisite for reasoning (i.e., cognitive ego functions) which, in turn, reduced the strength of his disposition to token "this is wrong" to a negligibly low value and, as a result, he did not in fact token "this is wrong" though, if the impairment of reasoning had not been present, the probability of his so tokening would have been materially greater.

Livermore \& Meehl, supra note 11, at 808.

Whatever else might result from this attempt to put "psycliological meat" on M'Naghten's "legal bones," id. at 800 , it introduces a version of "psychologist talk" into the definition which may or may not be compatible with the forms of analysis used by psychiatrists in assessing the defendant's mental state. Thus, such attempts to rewrite the tests will probably complicate, not simplify, the task. 


\section{The Nature of the Diminished Capacity Defense and Its Development in California}

"The 'diminished capacity defense' is a label attached to evidence that the defendant could not, and therefore did not, form the requisite mental state at the time of the commission of the charged offense." 58 The defendant introduces evidence, often of a highly technical nature, to show the absence of certain required mental elenients. ${ }^{59}$ The concept itself is not radical. If certain niental elements must be proven to justify a conviction, evidence showing that an elenient could not be present would seem highly probative. ${ }^{60}$ Yet, although the possibility of the defense was recognized long ago, ${ }^{61}$ it is unavailable in many jurisdictions. ${ }^{62}$

California's Wells-Gorshen line of cases exemplifies the analytic developnent of the defense. The reasoning carried the diminished capacity analysis to a point where courts eventually conducted detailed inquiries into the defendant's inental capabilities and the relationships between

58. Note, The Relevance of Innocence, supra note 15, at 1198 (footnote omitted). See generally Recent Developments-Diminished Capacity-Recent Decisions and an Analytical Approach, 30 VAND. L. ReV. 213 (1977). The Model Penal Code formulation of this concept, which would be applied to determine the presence or absence of the elements of criminal intent, provides: "Evidence that the defendant suffered from a mental disease or defect is admissible whenever it is relevant to prove that the defendant did or did not have a state of mind which is an element of the offense." Model Penal Code § 4.02(1) (Proposed Official Draft 1962).

59. The focus on mental elements distinguishes dimimished capacity from "diminished responsibility." The English Homicide Act of 1957 best exemplifies the latter defense. It reduces inurder to manslaughter when a person's "abnormality of mind . . . substantially impaired his mental responsibility." Homicide Act, 5 \& 6 Eliz. 2, ch. 11, $\S 2$ (1) (1957). In other words, the Act extends mercy to the offender because of his mental illness, even though the mens rea elements of the crime are present. See also Lewin, Psychiatric Evidence in Criminal Cases for Purposes Other than the Defense of Insanity, 26 SYRACUSE L. REV. 1051, $1054-65$ (1975) (distinguishing the "causative" doctrine of "partial responsibility" or "diminished capacity" from the "ameliorative" doctrine of "diminished responsibility").

Professor Lewin suggests that American courts are leery of diminished responsibility because it could work to the advantage of deranged sex killers and other unattracive defendants. Id. at 1058 . Thus, the doctrine has ouly found support when the killer is mentally retarded. Id.

60. In rejecting the restriction of evidence of diminished capacity to the sentencing stage of a bifurcated trial, the California Supreme Court agreed that:

"[A]s a matter of logic, any proof tending to show that a certain mental condition could not exist is relevant and should be admissible to show that it did not exist. And, of course, proof that something could not exist is the best possible evidence that it did not exist." People v. Wetmore, 22 Cal. 3d 318, 324, 583 P.2d 1308, 1312, 149 Cal. Rptr. 265, 269 (1978) (quoting Louisell \& Hazard, Insanity as a Defense: The Bifurcated Trial, 49 CALIF. L. REv. 804, 819 (1961)).

Similarly, the Pennsylvania Supreme Court regarded the use of psychiatric testimony on a defendant's ability to form a specific intent to kill as inerely an application of the rule that evidence that is probative and that advances the inquiry should be admitted absent some specific rule of exclusion. Commonwealth v. Walzack, 468 Pa. 210, 218, 360 A.2d 914, 918 (1976).

61. Lewin, supra note 59 , at 1061 \& n.44.

62. Id. at 1062, 1105-15 (identifying only 25 state and federal courts in which some form of the defense had been adopted, including Califorma, where it has since been outlawed). 
certain mental events. As a result, courts began to ask questions about mental life that were mcreasingly similar to those that psychiatrists ask, and began to rely on a wide range of psychiatric testimony in finding answers.

The Wells-Gorshen doctrine developed out of two landmark cases, which focused on "malice aforethought." The defendant in People v. Wells ${ }^{63}$ was a life prisoner who assaulted a guard, a capital offense at the time. $^{64}$ The defense offered evidence, in order to show the absence of malice aforethought, that Wells suffered from a condition in which he would react abnormally to external stimuli and feel excessive fear for his safety. The Califorria Supreme Court found it improper to exclude the evidence. ${ }^{65}$ The defendant in People v. Gorshen ${ }^{66}$ had suffered for years from sexually perverted trances and visions ${ }^{67}$ and, following a loss of sexual ability, came to see his job as central to his manhood. ${ }^{68}$ After an altercation with his supervisor, Gorshen felt so threatened with personality dismtegration that, according to expert testimony, he could think of nothing but going home, getting his gun, and returning to kill the supervisor, all of which he did. ${ }^{69}$ While affirming Gorshen's conviction for second-degree murder, the court concluded that a defendant is entitled to mtroduce psychiatric evidence showing that he is incapable of possessing the requisite mental state for the crime charged..$^{70}$

The Gorshen court treated "malice aforethought"71 as a specific mental element that must be proven. ${ }^{72}$ The court agreed that, in a murder case, malice aforethought means "something more" than "a wish to vex, annoy or injure another person," "73 although the exact nature of the element is difficult to discern. ${ }^{74}$ Whatever it is, lowever, the "defendant should be allowed to show that in fact, subjectively, he did not possess the

63. 33 Cal. 2d 330, 202 P.2d 53 (1949).

64. Id. at $334,202 \mathrm{P} .2 \mathrm{~d}$ at 56 .

65. Id. at 345-46, 202 P.2d at 62-63. The court stated a general rule concerning the admissibility of psychiatric evidence following a plea of not guilty: "[E]vidence, otherwise competent, tending to show that the defendant . . . either did or did not, in committing the overt act, possess the specific essential mental state, is admissible." Id. at 350-51, 202 P.2d at 66 (emphasis in original).

66. 51 Cal. 2d 716, 336 P.2d 492 (1959).

67. Id. at $722,336 \mathrm{P} .2 \mathrm{~d}$ at 495 .

68. Id.

69. Id. at 722,336 P.2d at $495-96$.

70. Id. at $731-36,336 \mathrm{P} .2 \mathrm{~d}$ at $501-04$.

71. In recent times, "malice aforethought" has not generally been interpreted to denote any specific state of mind, but rather only that the killing was intentional. See, e.g., Diamond, With Malice Aforethought, 2 Archives Crim. Psychodynamics 1 (1957); Purver, The Language of Murder, 14 U.C.L.A. L. REv. 1306, 1308 (1967).

72. Gorshen, 51 Cal. $2 \mathrm{~d}$ at 732-34, 336 P.2d at 498, 502-03.

73. Id. at 730,336 P.2d at $500-01$.

74. Id. at $730 \mathrm{n} .11,336 \mathrm{P} .2 \mathrm{~d}$ at $500 \mathrm{n} .11$ (devoting a lengthy footnote to the difficulty of determining what "malice aforethought" really means); $c f$. People v. Conley, $64 \mathrm{Cal} .2 \mathrm{~d} \mathrm{310,316-17,} 411$ P.2d 911, 915, 49 Cal. Rptr. 815, 819 (1966); Wells, 33 Cal. 2d at 356-57, 202 P.2d at 69-70. 
mental state or states in issue." 75

The court built on the Wells-Gorshen principle and applied it to intoxication in People v. Conley. ${ }^{76}$ There, the defendant had killed his former paramour and her liusband after a drinking binge. The Conley court discussed distinctions among malice aforethought and other mental elements of murder: .

[M]alice aforethought does not presuppose or require any ill will or hatred for the particular victim. . . . This mental state must be distimguished from that state of umind described as "wilful, dehiberate, and premeditated," however. The latter phrase encompasses the mental state of one who carefully weighs the course of action he is about to take and chooses to kill his victim after considering the reasons for and against it. . . . A person capable of achieving such a mental state is normally capable also of comprehending the duty society places on all persons to act within the law. If, despite such awareness, he does an act that is likely to cause serious injury or death to another, he exhibits that wanton disregard for hunan life or antisocial motivation that constitutes malice aforethought. ${ }^{77}$

Under the Conley analysis, intoxication, like mental disease, may negate malice aforetlought, a sensible result if one is concerned with mental elements per se. ${ }^{78}$ The Conley court also showed its concern with actual mental life when it observed that under Gorshen, imtent, deliberation, and premeditation may exist witliout malice. ${ }^{79}$

Similar concern with actual mental life appeared in People $v$. Wolff,, 80 an msanity case. Wolff, a fifteen-year-old boy suffermg from a mental disorder, looped to lure girls to his home for sexual purposes. Knowing that his motlier would interfere with these plans, he procured an axe liandle and beat her to death. ${ }^{81}$ The jury found him sane and convicted him of first-degree murder. The Califorma Supreme Court affirmed the findimg of sanity, but concluded that the murder was only second degree because the evidence did not adequately indicate a "wilful, deliberate, and premeditated" state of mind:

[T] he defendant had ainple time for any normal person to maturely and appreciatively reflect upon his contenplated act and to arrive at a cold, deliberated and premeditated conclusion. He did this in a sense ... [b]ut the extent of his understanding, reflection upon it and its consequences, . . . appears to have been inaterially—as relevant to appraising the quantuin of his moral turpitude and depravity-vague and

\footnotetext{
75. Gorshen, $51 \mathrm{Cal} .2 \mathrm{~d}$ at 733, $336 \mathrm{P} .2 \mathrm{~d}$ at 503 (emphasis added).

76. 64 Cal. 2d 310, 411 P.2d 911, 49 Cal. Rptr. 815 (1966).

77. Id. at 321-22, 411 P.2d at 918, 49 Cal. Rptr. at 822 (citations omitted).

78. Id. at 322, 411 P.2d at $918,49 \mathrm{Cal}$. Rptr. at 822 .

79. Id.

80. 61 Cal. 2d 795, 394 P.2d 959, 40 Cal. Rptr. 271 (1964).

81. Id. at $806,394 \mathrm{P} .2 \mathrm{~d}$ at $965,40 \mathrm{Cal}$. Rptr. at 278.
} 
detached. . . . [T]he use by the Legislature of "wilful, deliberate, and premeditated" $m$ conjunction indicates its intent to require as an essential element of first degree murder . . . substantially more . . . understanding and comprehension of the character of the act than the mere amount of thought necessary to form the intention to kill. ${ }^{82}$

With such subtle analyses of defendants' ratiocinations coming to figure into legal determinations, it is not an exaggeration to say that California was "asking the jury to make distmotions worthy of a medieval schoolmaster."83 The primary expertise for undertaking such subtle analyses lay, of course, with psychiatrists, not legal decisionmakers. Thus, psychiatric evidence of all kinds assumed increasing importance, mtroducing a wild card into the legal paradigm. One could not know from day to day how psychiatric developments or increasingly arcane judicial analyses of mental life would affect the ability of the criminal law to perforn its protective function. This was one of the concerns of California voters when they abolished the dimimished capacity defense. ${ }^{84}$

82. Id. at $822,394 \mathrm{P} .2 \mathrm{~d}$ at $976,40 \mathrm{Cal}$. Rptr. at 288 .

83. Arenella, The Diminished Capacity and Diminished Responsibility Defenses: Two Children of a Doomed Marriage, 77 CoLUM. L. REV. 827, 844 (1977). Professor Arenella specifically addresses the distinction between the capacity to intend a specific harm and the capacity to understand the nature and quality of one's acts, referring to People v. Ray, 14 Cal. 3d 20, 31, 533 P.2d 1017, 1023, $120 \mathrm{Cal}$. Rptr. 377, 383 (1975) (defendant cannot be guilty of a crime greater than involuntary inanslaughter where intoxication inakes malice and intent to kill impossible). Arenella, supra, at 843-44. Arenella indicates that the California developments with the diminished capacity defense altered the mens rea analysis from a search for specific mental eleinents to the consideration of any evidence that might tend to lessen the culpability of the defendant. Id. at 846-47. This conclusion is borne out by Wolff. That case also contains an interesting twist because the court felt compelled to provide a detailed analysis of mental events in order to give adequate consideration to "moral turpitude," which it regarded as at the heart of the legislative distinctions between degrees of inurder. People v. Wolf, 61 Cal. 2d 795, 394 P.2d 959, 40 Cal. Rptr. 271 (1964).

84. Cal. Penal Code $\S 25$ (West Supp. 1985) (enacted June 8, 1982, as a ballot initiative). The argunents in favor of the ballot initiative that eliuninated the diminished capacity defense stressed the need for protection against crime and decried "the ability of violent criminals to hidc behind the insanity defense." California Secretary of State, California Ballot PaMPHLET 34 (Prinary Eleetion, June 8, 1982). Evidently the electorate was less confident than some courts that civil commitment provided adequate societal protection. See, e.g., People v. Wetmore, 22 Cal. 3d 318, 329, 583 P.2d 1308, 1316, 149 Cal. Rptr. 265, 273 (1978).

Public attention was draniatically drawn to the dimimished capacity defense by the manslaughter verdict returned in the trial of former San Francisco Supervisor Dan White for the November 1978 killings of Mayor George Moscone and Supervisor Harvey Milk. For a journalistic account of the killings, the trial, and the riot immediately following the verdict, see M. WE1Ss, DoubLE PLAY: The SAN Francisco CTTY Hall KILlings (1984). Legislative hearings on dininished capacity were held approximately one year after the killings. The Defenses of Diminished Capacity and Insanity: Hearings Before the Joint Comm. for Revision of the Penal Code of the Senate Comm. on Judiciary and Assembly Criminal Justice Comm., Cal. Legislature (1979) [hereinafter cited as Diminished Capacity Hearings]. 


\section{Paradigm Protection and Reactions to the Diminished Capacity Defense}

This Section discusses judicial efforts to preserve the integrity of the legal systein in the face of perceived threats engendered by the diminished capacity defense. These efforts illustrate both the nature of judicial concerns and two possible protective responses: narrowly defined boundaries and rejection..$^{85}$

Pennsylvania's consistent refusal to accept the "irresistible impulse" concept has provided its courts with a convernent inechanisin for limiting the reach of the diminished capacity defense. Pelmsylvarna first accepted the diminished capacity defense, over a vigorous dissent, in Commonwealth v. Walzack. ${ }^{86}$ The Walzack court permitted psychiatric evidence on the issue of whetlier the defendant, who liad undergone a lobotoiny, had the capacity to form the specific intent required for first-degree murder. ${ }^{87}$ The majority's reasoning was straightforward: the legislature liad defined the inental eleinents of specific intent for first-degree inurder; the state was required to show them; the defense was entitled to offer reliable rebuttal evidence; and psychiatry liad becoine sufficiently rehable to advance the inquiry concerning the presence of these mental elements. ${ }^{88}$

In reaching its decision, however, the Walzack court carefully distinguished diminished capacity froin irresistible impulse:

Irresistible impulse is a test for insanity which is broader than the M'Naghten test. Under the irresistible impulse test a person may avoid criminal responsibility even though he is capable of distimguishing between right and wrong, and is fully aware of the nature and quality of his act provided he establishes that he was unable to refrain from acting. An accused offering evidence under the theory of dimimished capacity

85. Judicial efforts to himit the effect of psychiatric testimony can be assessed at two levels. Professor Lewm, looking largely to the logic of the "causative" (diminished capacity) analysis, adopts one of these:

To dismiss the defense because the state of the development of psychiatry is not so exact as to permit the practitioner to describe the workings of the mind is not only an arrogaut reservation of power by those charged with legal decision-making; it is also out of keeping with the traditional . . . laws of evidence [statiug that] where an issue cannot be resolved by a factfinder because the questions involved do not lie within the common experience or knowledge of the lay commumity theu witnesses skilled . . . in the particular . . . science called into relevancy may assist the factfinder....

Lewin, supra note 59, at 1096-97.

The courts may, however, be reacting at a second, much more fundamental level, protecting what they believe to be their basic function from a perceived threat. If this coucern is the basis for judicial rejection or limitation of the diminished capacity doctrine, then it is not clear whether that judicial view should be attributed to arrogance rather than to humility and diligence.

86. 468 Pa. 210,360 A.2d 914 (1974).

87. Id. at $214-16,360$ A.2d at $916-17$. At that time, Pennsylvania law defined the specific intent for first-degree murder (except felony unurder) as "willful, dehberate and premeditated." Id. at $216,360 \mathrm{~A} .2 \mathrm{~d}$ at 917 .

88. Id. at $217-19,360$ A.2d at $917-18$. 
concedes general criminal liability. The thrust of this doctrine is to challenge the capacity of the actor to possess a particular state of mind required by the legislature for the commission of a certain degree of the crime charged. ${ }^{89}$

Despite this careful distinction, the dissent feared that the majority was joining forces with those psychiatrists who "will continue to dig up excuses for criminal behavior."90 It felt the majority attributed to psychiatry a false degree of precision in distinguishing among mental states. $^{91}$ These fears also surfaced in other Pennsylvania cases.

In an earlier case, Commonwealth v. Weinstein, ${ }^{92}$ an evenly divided court had uplield the trial court's refusal to allow use of the diminished capacity defense. ${ }^{93}$ Following Walzack, Weinstein appealed again and lost unanimously on the issue of the introduction of psychiatric testimony on specific intent. ${ }^{94}$ The Weinstein II court did not reject Walzack; rather, it carefully reviewed the testimony offered at Weinstein's sentencing learing and concluded that it went only to the issue of irresistible inipulse, not specific intent. ${ }^{95}$ The interpretation of Walzack in Weinstein II lias distinctly psychiatric overtones:

Walzack stands for the proposition that psychiatric testimony relevant to

89. Id. at $221,360 \mathrm{~A} .2 \mathrm{~d}$ at 920 (emphasis in original).

90. Id. at 224, 360 A.2d at 921 (Eagen, J., dissenting).

91. The dissent argued:

Today a unajority of the court . . . attributes to the science of psychiatry the ability to say with a reasonable degree of certainty that the instant killer, who admittedly was sane and acted with malice and had the mental capacity to know what he was doing and to know what he was [d]oing was wrong, lacked the mental capacity to form a specific intent to kill.

Id. (Eagen, J., dissenting) (emphasis in original) (footnote ounitted).

92. 442 Pa. 70, 274 A.2d 182 (Weinstein I), cert. denied, 404 U.S. 846 (1971).

93. Id. at 85, $274 \mathrm{~A} .2 \mathrm{~d}$ at 191 . Weinstein had tricked his victin into ingesting sleeping pills, apparently so that he could remove the victim's trousers and shred them for his sexual gratification. As he viewed the sleeping victim, Weinstein was suddenly overcome by a powerful sexual urge, under the influence of which he strangled the victim to death. Id. at 75-76, 274 A.2d at 186-87.

The court also reiterated the conclusion of a prior case that the courts cannot abdicatc to psychiatry " 'the task of determiming criminal responsibility" " or " "the right to determine the intent or the state of mind of an accused." "Id. at 85, 274 A.2d at 191 (quoting Coununonwealth v. Carroll, $412 \mathrm{~Pa} .525,537,194$ A.2d 911, 918 (1963)). In that earlier case, the Pennsylvania court had been faced with an extreme defense theory in the defendant's brief: "Does not the evidence of defendant's good character, together with the testimony of inedical experts . . . that the homicidc was not premeditated or intentional, require the Court below to fix the degree of guilt of defendant no higher than inurder in the second degree?" " Commonwcalth v. Carroll, 412 Pa. 525, 527-28, 194 A.2d 911, 913 (1963) (emphasis added by court) (footnote omitted). Such an extreme argument is likely to be rare in practice. A inore rcalistic concern would be that the routine adinission of highly technical psychiatric information would approximate this result. II).

94. Commonwcalth v. Weinstein, 499 Pa. 106, 119, 451 A.2d 1344, 1350 (1982) (Weinstein

95. Id. at $112,451 \mathrm{~A} .2 \mathrm{~d}$ at $1346-47$. In Weinstein $I$, the testimony that had been refused involved the question of the defendant's ability to form the requisite specific intent. $442 \mathrm{~Pa}$. at 77-78, 274 A.2d at 187. It is not clear from Weinstein $I I$ whether the testimony purported to address specific intent and the court rejected that contention, or whether the psychiatrist was unable to offer an opirion concerning specific intent at the sentencing hearing. 
tlie cognitive functions of deliberation and premeditation is competent on the issue of specific intent to kill. Thus psychiatric testimony is competent in Pennsylvamia on the issue of specific intent to kill if it speaks to mental disorders affecting the cognitive functions necessary to formulate a specific intent. Where, as liere, it does not, it is irrelevant and lience inadmissible. ${ }^{96}$

The court maintained, in effect, that an irresistible impulse is not a psychiatric disorder of the type that can destroy the cognitive functions of premeditation and deliberation. The court appeared unconcerned with the psychiatric validity of its own analysis.

As a matter of syllogistic logic one might consider irresistible impulse as valid a talisman for the determination of criminal imtent as the ability to distinguisl right from wrong. The refusal of jurisdictions sucl as Pennsylvania to accept it is based not on such logic, but on policy. . . .

The law, in its effort to sliape a rational social policy, grounded in the broadly shared assumptions of the mdividuals wlio make up society, cannot admit that acts an individual carefully plans and carries out to advance his own desire, wlien he knows tlose acts will result in the deatli of anotlier liuman being, will not be punislied simply because of the intensity or strangeness of that desire. . . . Along the psyclioanalytic continuum tlie outrageous proves the innocence. . . . Suclı analysis may be medically useful. It is not legally useful. ${ }^{97}$

In protecting its ability to shape pohicy, the Weinstein $I I$ court restricted psychiatric evidence to areas where, in its opinion, legal and psychiatric concepts overlapped. ${ }^{98}$ Everything outside these narrowly defined boundaries was legally irrelevant.

Taken together, Walzack and Weinstein II present the curious situation of judges deciding what types of psychiatric evidence speak to which niental states. This puts the expert in the awkward position of having to speak about the defendant in legally prescribed terms when describing niental life, rather than in a way that is most informative from the expert's perspective. As instruments of social pohicy, courts are justified, perhaps even conıpelled, to prevent disruption of their functions. However, this type of approach inhibits the full use of psychiatric inforniation through an excessively formal and technical view of the relation-

\footnotetext{
96. Weinstein $I I, 499 \mathrm{~Pa}$. at $114,451 \mathrm{~A} .2 \mathrm{~d}$ at 1347 .

97. Id. at 116-17, $451 \mathrm{~A} .2 \mathrm{~d}$ at 1349 (footnote omitted).

98. Id. at 117-18, $451 \mathrm{~A} .2 \mathrm{~d}$ at 1349-50:

Although we do not exclude expert medical testimony on causation because its definitions differ from ours, we do require that medical testimony speak to us in our language and we accept it only where the two concepts overlap. ...

Inability to speak in terms of the legal concept of specific intent, but only in the determinist language of irresistible impulse is instructive in analyzing the general reluctance of many courts to admit such testimony ... . The element of specific intent in the first degree murder statute is a legal construct which bears only a coincidental resemblance to psychiatric definitions.
} 
ship between psychiatric and legal concepts. ${ }^{99}$

Commonwealth v. Zettlemoyer ${ }^{100}$ further clarifies Pennsylvania's constraints on psychiatric analysis. Zettlemoyer had taken his handcuffed victim into the woods and shot him several times, apparently to prevent the victim from testifying in another trial. ${ }^{101}$ The psychiatrist discussed the defendant's personality disorder in detail. However, the trial court would not admit his opinion as to whether or not the defendant could form the specific intent required for first-degree murder. It ruled that on the basis of the evidence, the psychiatrist could not reasonably conclude that specific intent was lacking. ${ }^{102}$ The supreme court approved the trial court's assessment, finding that all of the testimony addressed irresistible impulse. ${ }^{103}$ It also added that "personality disorders or schizoid/paranoid diagnoses are [ir]relevant to a Walzack/diminished capacity defense" and endorsed the trial court's conclusion that the psychiatrist's entire testimony could have been struck. ${ }^{104}$

The net effect of these decisions is that the trial court has two ways to exclude practically any psychiatric testimony. The court can classify the evidence as an attempt to import the irresistible impulse test under the guise of diminished capacity. Alternatively, it can exclude the evidence if it cannot comprehend the relationship between the psychiatrist's diagnostic analysis and particular mental elements used by the law-even though, as would probably have been the case in Zettlemoyer, the psychiatrist can. And yet, if the law's mental elements are taken to have actual existence, determination of which psychiatric concepts relate to which

99. The same basic problem was noted by Justice McDermott in his memorandum in Weinstein II, opposing the use of psychiatric testimony for other than M'Naghten purposes:

This case, with its distinctions and justifications, affirms that "psychiatric evidence" is admissible when relevant. It does not say that that evidence must be relevant under the M'Naghten Rule. In short, it plunges us into determmations that are and will be experimental at best, leaving the trial courts without guidance and our dockets filled.

Id. at 121, 451 A.2d at 1351 (McDermott, J., commenting).

Psychiatrists may view the requirement to speak in terms of legally defined mental elements as a major hurdle to be cleared in order to present a thorough account of the defendant's behavior. Consider Dr. Diamond's characterization of this hurdle:

I concede that this whole business of lack of mental capacity to premeditate, to have malice or to entertain intent, is a kind of sophistry which must not be allowed to remain an end $\mathrm{m}$ itself. Right now we must utilize these legal technicalities to permit the psychiatrists to gain entrance into the trial court and to allow the judge and jury to give full consideration to the deeper and more complex mental and emotional factors of the defendant. I think that it would even be improper for the psychiatrist to attempt precisely to fit his psychiatric knowledge into the technical and legalistic distinctions made by the law between these various elements of mens rea.

Diamond, Criminal Responsibility of the Mentally Ill, 14 STAN. L. REv. 59, 82 (1961).

100. 500 Pa. 16, 454 A.2d 937 (1982), cert. denied, 461 U.S. 970 (1983).

101. Id. at $25-26,454$ A.2d at $941-42$.

102. Id. at 28-30, 454 A.2d at $943-46$.

103. Id. at $33-35,454 \mathrm{~A} .2 \mathrm{~d}$ at $946-47$.

104. Id. at 30, $454 \mathrm{~A} .2 \mathrm{~d}$ at 944. 
mental events is a technical question within the domain of psychiatry, not the law. Courts' retention of decisionmaking power shows clearly that they feel it is necessary to keep policy control. ${ }^{105}$

Concern about preserving the roles of the legislature and the jury may lead to refusal to allow the diminished capacity defense to be used to address malice aforethought. In State $v$. Schantz, ${ }^{106}$ the defendant requested a diminished capacity instruction on the issue of matice aforethought in an effort to reduce the crime front second-degree murder to manslaughter. ${ }^{107}$ The Arizona Supreme Court upheld the trial court's refusal to give the instruction, declining to follow either the Wells-

105. A similar pattern of imitial acceptance and subsequent limitation of the diminished capacity defense appears in New Jersey. In State v. DiPaolo, 34 N.J. 279, 168 A.2d 401, cert. denied, 368 U.S. 880 (1961), the New Jersey Supreme Court found that the existence of the "mental operations" of premeditation, deliberatiou, and willfulness are "matters of fact" and that a trial court may not exclude psychiatric testimony that rationally bears on them. Id. at 294-97, 168 A.2d at 409-10 (emphasis in origiual). Yet, four years later, iu State v. Sikora, 44 N.J. 453, 210 A.2d 193 (1965), the court held that psychiatric testimony concerning unconscious influences that removed the defeudant's ability for conscious premeditation could properly be excluded. Id. at 472, 210 A.2d at 203 . The justices behaved much like scientists rejecting a proposed new paradigm:

For protection of society the law accepts the thesis that all men are invested with free will and capable of choosing between right and wrong. In the preseut state of scientific knowledge that thesis canuot be put aside in the administratiou of the crimiual law. . . . In a world of reality [persons whose actions are controlled by unconscious motivations] must be held responsible for their behavior.

Trite as it may sound to some, the law must distinguish between mental disease and character deformity. . . .

If a person thinks, plans and executes the plan at [the conscious] level, the criminality of his act cannot be denied [merely] because . . . his conscious was influenced to think, to plan and to execute the plan by unconscious influences ..... If the law were to accept such a medical doctriue [of control by uncouscious influences] as a basis for a findiug of second rather than flrst degrec murder, the legal doctrine of mens rea would all but disappear . . . . Applying [this psychiatrist's] theory to crimes requiring specific iutent . . . it is difficult to imagine an individual who perpetrated the deed as having the mental capacity in the criminal law sense to conceive the intent to commit it. Criminal responsibility, as society now knows it, would vanish from the scene, and some other basis for dealing with the offender would have to be found. At bottom, this would appear to be the ultimate aim of the psychodynanmic psychiatrists.

Id. at 470-71, 210 A.2d at 202-03. Restructuring the evidence for consisteucy with more traditional legal analysis, the Sikora court characterized Sikora's criminal act as "uothing more than the cousequence of an impulse that was not resisted." Id. at 472, 210 A.2d at 203.

106. 98 Ariz. 200, 403 P.2d 521 (1965), cert. denied, 382 U.S. 1015 (1966).

107. The defendant had stabbed and beaten his wife to death in the course of a fight. Id. at 204, 403 P.2d at 523. The trial judge had deterinined that the premeditation and deliberation required for first-degrec murder were not present and directed a verdict of acquittal on that charge. Id. at 205, 403 P.2d at 524. The defendant's requested instruction read, in part:

It should be noted that a character or behavior disorder, the nature or severity of which is such that it may have interfered with the aceused's capacity to contrive and desigu, may coustitute evidence tending to negate the accused's capacity to entertain the required malice aforethought, specific inteut or knowledge.

You are advised that an accused may be mentally responsible in a general criminal sense and yet, because of some underlying mental impairment or deficiency, be meutally incapable of entertaiuing the (intentional design to kill) (specific intent) involved in the offense of murder. You should therefore consider, in connectiou with the other evidence, the evidence tending to show that the accused was suffering from a mental impairment, defect, disorder, or deficieucy in determining whether he had sufficient mental capacity to 
Gorshen approach ${ }^{108}$ or the Model Penal Code formulation. ${ }^{109}$ It reasoned that the diminished capacity defense introduced volitional elements into the analysis contrary to the legislatively enacted cognitive approach of M'Naghten, which the court took to be the only proper use of psychiatric evidence under Arizona law. ${ }^{110}$

The court noted that the legislature had set up a complete system for assessing homicide that, while sometimes difficult to apply, was a workable one free of paradoxes. ${ }^{111}$ Responsibility for change, it felt, rested with the legislature. ${ }^{12}$ It thus rejected a jury instruction that would have had the practical effect of bringing volitional defects into consideration, contrary to the legislative definition of malice. ${ }^{113}$

The Schantz court also expressed concern that acceding to the defendant's request would place jurors in an untenable position, both logically and ethically. It would force them to ignore either the existing law or the evidence presented. The court explained:

To instruct as defendant proposes would present conscientious jurors with an almost unresolvable dileının. If they found the facts to be that there was no considerable provocation sufficient to reduce the crime to manslaughter, they would, under the law of this state, be required to find nalice and return a verdict of guilty of second degree murder, but the evidence is froin credible inedical experts that defendant cannot be guilty of second degree murder because there was in fact no malice. (Nor could the jury return a verdict of inanslaughter because the circumstances of the killing did not present adequate provocation.) Jurors are thus put to this choice: Either to violate their oaths as jurors and disregard the law returning a verdict of not guilty; or close their minds to the evidence of the accused's principal and perhaps only defense, evidence they inay honestly believe, and return a verdict of guilty. ${ }^{114}$

Because the existing system created no such contradictions, the court decided to reject the defense.

Professor Kuhn might have predicted the protective responses of

entertain, and did in fact entertain the (malice aforethought) (specific intent) involved in the offense of murder.

Id. at $205 \mathrm{n} .1,403$ P. $2 \mathrm{~d}$ at 524 n.1.

108. Id. at 210-13, 403 P.2d at 528-29. For further discussion of the Wells-Gorshen doctrine, see supra notes $63-75$ and accompanying text.

109. Schantz, 98 Ariz. at 207-12, 403 P.2d at 526-29; see supra note 58 for the Model Penal Code formulation.

110. 98 Ariz. at 207-08, 403 P. $2 \mathrm{~d}$ at 526.

111. Id. at $205,403 \mathrm{P} .2 \mathrm{~d}$ at 524 .

112. Id. at $212-13,403$ P.2d at 529 .

113. Id. The court stated that " $[t]$ he legislature has provided that malice shall be implied where there is an unlawful killing with no considerable provocation. It has not recognized a disease or defect of mind in which volition does not exist-even if some psychiatrists [have] - as a defense to a prosecution for murder." Id. at 212, 403 P.2d at 529.

114. Id. 
both these courts faced with perceived threats to the law's problem-solving ability. Pennsylvania's formalistic limitations based on its strict differentiation between irresistible impulse and diminished capacity sharply restrict the way psychiatric evidence may be used. The court rejected the irresistible impulse defense-an alternative paradigm - to ensure that it would not lose policy control. In Arizona, psychiatric evidence threatened to disrupt tlie proper roles of the legislature and jury within the legal paradigm. Since, as a practical matter, no viable alternative paradigm was available, ${ }^{115}$ the court rejected psychiatric evidence to sliow dimimislied capacity.

Such responses result from the tendency of the dimimished capacity defense to give psychiatric meaning to legal concepts. Unlike expert evidence on the battered woman syndrome, for example, psychiatric evidence of specific intent goes all too directly to the ultimate issue of guilt. As a result, the evidence may appear to determine the outcome and to dominate traditional legal decisionmakers. Given the dissimilarity in the underlying values of the two disciplines, the law is unwilling to replace its existing paradigm with one based on psychiatry. Thus its response is drastically to restrict psychiatric testimony im this context.

III

\section{USE OF PSYChIATRIC INFORMATION BY THE LAW}

The above examples demonstrate that psychiatric evidence is most useful when the law neither attempts to equate its concepts with those of psychiatry nor tries to speak in terms that suggest quasi-psychiatric assessments of actual inental hife. Instead, the best approach is for the law to define its crimes and defenses in broad, psychiatrically naive terms. It then can permit the jury to consider a wide range of psychiatric information in applying such standards. ${ }^{116}$

Lord Clief Justice Parker took such an approach in his analysis of the operation of the English Homicide Act ${ }^{117}$ in Regina v. Byrne. ${ }^{118} \mathrm{He}$

115. Id. at 212-13, 403 P.2d at 529 (while confident that the Model Penal Code formulation was adequate, the court felt that it lacked the authority to adopt it judicially).

116. Even when a defense is formally structured around mental elements themselves, a defense attorney may employ psychiatric evidence for its broader explanatory effect. See, e.g., Diminished Capacity Hearings, supra note 84, at 169-71 (statement of Edward Rucker, Head Deputy of the Los Angeles County Public Defender's Office, Pomona) (arguing that the real function of psychiatric testimony is to marshal and articulate those factors that human experience tells us a jury will consider, such as: "The background of individuals. What they've had to go through in their life. What result it's had in their personality and character.").

117. The Act reads, in part:

Where a person kills or is a party to the killing of another, he shall not be convicted of murder if he was suffering from such abnormality of mind (whether arising from a condition of arrested or retarded development of mind or any inherent causes or induced by disease or injury) as substantially impaired his mental responsibility for his acts and omis- 
indicated that the threshold question of whether or not the defendant displayed an "abnormality of mind" was for the jury; medical evidence would be relevant to, but not determinative of, that question. ${ }^{119}$ Likewise, scientific evidence was not capable of distinguishing between " "he did not resist lis impulse" " and " 'le could not resist his impulse" ": 120 "tlie jury can only approach [such issues] in a broad, common-sense way." 121 He reasoned that medical evidence would, however, help the jury to determme whether or not the defendant's abnormality substantially lowered his responsibility for a killing. ${ }^{122}$ The jury would decide whether or not the abnormality in fact lowered responsibility, just as juries determine the issue of a defendant's reasonableness in the traditional defense of provocation.

This approach to the English Homicide Act broadly sets out a policy for judges and juries to apply in assessing culpability, but does not use legally defined mental states as intermediaries. Such an approach may prove more conducive to the introduction of thorough psychiatric analyses than one relying on the identification of specific mental elements of a crime. ${ }^{123}$

In one respect, the approach of the New Jersey court in State v. Sikora ${ }^{124}$ is strikingly similar to that of Lord Chief Justice Parker. Both perumit relatively free use of psychiatric evidence in assessing the level of criminal responsibility, ${ }^{125}$ but resist letting the issue of responsibility itself be reduced to psycliatric terms. ${ }^{126}$

The law may take into account the defendant's peculiarities and the circumstances of his act with or without an investigation of his actual state of mind. This is exemplified by the jury instructions recommended

sions in doing or being a party to the killing.

Homicide Act, 5 \& 6 Eliz. 2, ch. 11, § 2(1) (1957).

118. [1960] 2 Q.B. 396.

119. Id. at 403 .

120. Id. at 404 .

121. Id.

122. Id. at $402-04$.

123. A similar analysis may underlie Dr. Diamond's call for "a radically new relationship between psychiatry and the law . . . . in which each profession respects the basic tenets of the other, and neither usurps the functions of the other." Diamond, supra note 99, at 84. Dr. Diamond would prefer that psychiatrists be allowed to provide a comprehensive analysis of the roots of the defendant's actions, without being asked to cast the discussion in conclusory legal terms. Id. at 83-84.

124. 44 N.J. 453, 210 A.2d 193 (1965). For a discussion of the Sikora ease, see supra note 105.

125. The Sikora court would admit psychiatric evidence for sentence determination so that "[i]f the psychodynamic psychiatric testimony persuasively reveals a personality dysfunction on the part of the defendant, the common sense of the jury can be counted on to assess the matter of limited or diminished criminal responsibility . . to reduce the degree of moral culpability." 44 N.J. at 472 , $210 \mathrm{~A} .2 \mathrm{~d}$ at 203 . Evidently, the court did not perceive the same potential for disruption from such a use of the evidence as it perceived from its usc in determining guilt.

126. The Sikora court limited the domain of mental elements for which psychiatric evidence was even potentially admissible in the guilt phase to those "established in law for the determination of criminal responsibility." Id. at 469-70, 210 A.2d at 202. 
by the California Supreme Court in People v. Conley. ${ }^{127}$ Those instructions read, in part:

Voluntary manslaughter [is] an intentional killing in which the law, recognizing human frailty, permits the defendant to establish the lack of nalice either by

a. Showing provocation such as to rouse the reasonable man to heat of passion or sudden quarrel. When such provocation is shown, the law will presume that the defendant who acts in the heat of passion or on sudden quarrel, acts without malice. . . .

b. Showing that due to dimimished capacity caused by mental illness, mental defect, or intoxication, the defendant did not attain the mental state constituting malice. ${ }^{128}$

Thus, for "reasonable inan provocation" expressed above by part $a$, surrounding events may preclude a finding of inalice, whatever the actual state of inind of the killer. Finding such reasonable provocation is a nonpsychiatric decision, although the factfinder may find psychiatric information useful in making it. Indeed, it would not change the substantive analysis to replace the italicized sentence with "When such provocation is shown, the highest degree of criminal responsibility that can be charged to the defendant is manslaughter."

By contrast, if the concept of mahice were removed from part $b$ of the instructions, the required analysis would change greatly; it would move in the direction of the English Hoinicide Act. That statute prohibits a inurder conviction if the defendant's abnormality of mind is found to "substantially [inpair] his mental responsibility" for the killing. However, the Act does not operate through the negation of any particular inental element of the crime. ${ }^{129}$

This discussion does not advocate adoption of the specific policies embedded in the English Homicide Act. Rather, it suggests that whatever policies are adopted-and these will vary from jurisdiction to jurisdiction-they should be stated and, even more importantly, employed in a psychiatrically naive way. That is, they should express societal standards, policies, and objectives, not in psychiatric or quasipsychiatric terms, but in lay language. One hopes these standards will reflect a humane understanding of human frailties. Then, when employing these standards, psychiatric expertise can enrich the information available to the factfinder without threatening to dictate the result. ${ }^{130}$

127. 64 Cal. 2d 310, 411 P.2d 911, 49 Cal. Rptr. 815 (1966).

128. Id. at $325 \mathrm{n} .4,411 \mathrm{P} .2 \mathrm{~d}$ at $920 \mathrm{n} .4,49 \mathrm{Cal}$. Rptr. at $824 \mathrm{n} .4$ (emphasis added).

129. See supra note 117 .

130. For a discussion by a former prosecutor experienced with diminished capacity cases advocating the application of the jury's ethical judgment in light of all the circumstances, see Diminished Capacity Hearings, supra note 84, at 138-43 (statement of Ronald Tochterman, Judge of the Munici- 


\section{CONCLUSION}

The law is a social system, the major goal of which is to protect society from undesirable conduct. In reaching for this goal, the law does not respond reflexively to the wrongdoer; rather, it tempers its response by considering the offender's mental pecuharities and the circumstances surrounding his actions. Because the law considers such factors, psychiatry should be of great value. However, to realize its full potential, it is critical that psychiatry not disrupt the puzzle-solving ability of the legal paradigm. At the same time, psychiatric concepts should not be forced into legally defined pigeonholes.

The utility of psychiatry for legal decisionmaking depends upon the relationships between the concepts in the two systems. When these relationships are too close, it is increasingly hikely that psychiatry will be perceived to threaten the ability of the law to effect the policies for which it is designed. If so, the law will react to preserve its ability to carry out these policies no matter what more formal psychiatric analyses might suggest. However, there is great potential for effective interaction between the two disciplines. Perhaps the best course for those who would like the courts to make better use of psychiatric inforination is to encourage society to adopt broad, humane standards for the assessment of wrongdoers. Within this framework, factfinders could consider all of the information that can help to illuminate wrongful acts. Society, however, must delimit in a nontechmical way what it will and will not tolerate, and low it will respond to the offender. Such an approach allows society to retam the control necessary to protect itself while modulating its reaction in light of the best infornation that psychiatry can provide.

Peter R. Dahl*

pal Court, Sacramento County). Judge Tochterman advocates adoption of a statute similar to the English Homicide Act and also respects Lord Chief Justice Parker's analysis in Byrne.

* B.A. 1968, Macalester College; Ph.D. 1973, University of Minnesota; third-year student, Boalt Hall School of Law, University of California, Berkeley. 